\title{
Three Shortcomings of the Social Investment Perspective
}

\author{
Bea Cantillon* and Wim Van Lancker** \\ *Herman Deleeck Centre for Social Policy, University of Antwerp \\ E-mail:Bea.Cantillon@ua.ac.be \\ **Herman Deleeck Centre for Social Policy, University of Antwerp \\ E-mail: Wim.VanLancker@ua.ac.be
}

In this article we critically assess the social investment perspective that has become the dominant paradigm in European social policymaking. We identify and discuss some of its shortcomings that may hamper social progress for all. In doing so, we focus on three pillars central to the idea of social investment: social inclusion through work, individual responsibility and human capital investment. We find that the social investment perspective has some serious flaws when it comes to the social protection of vulnerable groups. This is strongly related to the continuing relevance of social class in explaining and remedying social inequalities. We conclude that investment cannot be the only rationale for welfare state intervention and that protecting people should remain equally high on the policy agenda.

Keywords: Social investment, welfare state change, care, individual responsibility, human capital.

\section{Introduction}

Social investment constitutes a set of policies and ideas that emerged in the mid-1990s as a response to profound and fundamental changes in the labour market and in the demographic structure of societies, and the emergence of new social risks and needs (Hemerijck, 2013). The introductory article of this themed section showed how welfare states responded to the changed circumstances, and how a new welfare settlement was found in an 'opportunity-driven logic' (Taylor-Gooby, 2011). Before presenting the aim, method and structure of this contribution, we first highlight the basics of the social investment perspective, which is now considered to be the dominant paradigm for appreciating the policy logic of contemporary welfare states (Morel et al., 2011; Bonoli and Natali, 2012; Cantillon and Vandenbroucke, 2013).

The core idea underlying social investment is that social policy should no longer focus on 'passively' protecting people from the perils of the market by means of cash benefits, but rather prepare or 'empower' people in order to maximally integrate them into the market (Jenson and Saint-Martin, 2003). Labour market integration is not only regarded as a superior way to achieve income protection and social inclusion at the individual level, but is also an indispensable feature of 'productive' social policy systems because higher employment levels decrease benefit dependency and contribute to sound public finances, and hence to the future sustainability of the welfare state. The prime channel to achieve this ideal of social inclusion through labour market participation is long-term investment in human capital, to begin in early life (Hemerijck, 2012). This ought to ensure productivity 
improvement for future generations and bestow upon individuals the necessary skills to take the available opportunities in a knowledge economy and, in the end, break the intergenerational chain of poverty (Esping-Andersen et al., 2002). By default, this entails a shift in social protection, from the collective to individual responsibility (Cantillon and Van Lancker, 2012). A social investment environment creates the necessary conditions but it is up to the people themselves to maintain responsibility for safeguarding their own welfare. The focus on paid employment, for instance, presupposes a commitment to looking for a job and the responsibility to accept suitable employment. The result is a shifting balance between social rights and duties. In short, the new welfare logic can be aptly described as 'preparing rather than repairing' or, to use an appealing metaphor, social policy should become a 'trampoline' instead of a 'safety net' (Jenson, 2012).

What we have presented is a short summary of the basic principles of the social investment perspective, but not all reform trajectories in European welfare states have necessarily followed this exact path (for example, Taylor-Gooby, 2008; Palier, 2010; Morel et al., 2011). This can be traced back to the different intellectual and political influences that have shaped the social investment perspective in different countries. A case in point is the fact that the two key publications underpinning the intellectual framework of social investment, The Third Way (Giddens, 1998) and Why We Need a New Welfare State (Esping-Andersen et al., 2002), are at odds regarding the role of social protection. While social investment as put forward by Giddens should ultimately replace traditional forms of social protection, an interpretation that heavily influenced Third Way politics (Lister, 2003), Esping-Andersen et al. draw on the Scandinavian variety of social investment ${ }^{1}$ to argue against Giddens that social investment and traditional social protection are both indispensable: 'income security is a precondition for an effective social investment strategy' (Esping-Andersen et al., 2002: 5). We will come back to this intrinsic ambiguity in the discussion; at this point it is important to acknowledge that social investment is not a full-fledged and necessarily coherent paradigm, but a set of ideas which can be and have been interpreted and implemented in different ways.

Irrespective of this ambiguity, however, it is safe to say that the social investment way of framing problems and solutions concerning social protection is now widely shared across countries, in as well as outside of the European Union (Peng, 2011; Cantillon and Van Lancker, 2012; Jenson, 2012), and firmly backed by influential international organisations such as the OECD, UNICEF and the World Bank. At the European level, the basic principles were diffused through the Lisbon Agenda in 2000 and in its subsequent EU2020 strategy (Cantillon, 2011; Daly, 2012; Peña-Casas, 2012). Given its omnipresence in today's policymaking discourse and practice, the social investment perspective adds an important dimension to the 'old' forms of social protection (Cantillon, 2013). Insofar as its focus on investing in human capital, maximising employment and individual responsibility is a functional and rational response to new needs and circumstances, governments cannot be too ambitious in applying the social investment recipe to social policy renewal.

This must not prevent us from locating its shortcomings and problems, however. Influential ideas should withstand a critical assessment, certainly so if they are to become the encompassing concept of social policy in Europe. That is our aim in this article. Previous research has questioned the new policy logic on the grounds of its performance in relation to poverty outcomes (Cantillon, 2011; Vandenbroucke and Vleminckx, 2011). Here we take a different approach. We aim to identify and discuss shortcomings of the 
social investment perspective that might hamper social progress for all. Drawing on our own and others' research we will critically assess the three pillars of the social investment perspective we identified above, both at the ideational and the policy level, in European countries.

First, we will discuss the notion of 'social inclusion through work' in relation to people who cannot be readily expected to engage in paid employment and, more broadly, the notion of unpaid care work. Second, we will confront the idea of 'individual responsibility' with the reality of conditional benefits applied to steer human behaviour and its outcomes. Finally, we will ascertain what to expect from 'human capital investment' in terms of mitigating social inequalities using the example of childcare services. We end this piece by relating the shortcomings of the social investment perspective to its future as a guiding principle for social policy.

\section{Social inclusion for the non-productive: the case of the disabled}

The first shortcoming of the social investment paradigm is this: if social policy is founded on the assumption that employment is a fast-track to social inclusion, and policy reforms are consequently oriented towards activation (which has indeed happened over the past decades as we shall see below), a genuine problem arises concerning the social protection of those people who cannot be integrated into the labour market - for whatever reason. We will make this point by focusing on the case of the physically or mentally impaired, following in Martha Nussbaum's footsteps. In Frontiers of Justice (2006), she introduces children with different but severe mental or physical impairments to discuss the difficulties and peculiarities of their situation in a context where individuals are expected to be 'productive citizens' (as opposed to being dependent on benefits). Some of those children with impairments will be able to hold a job in the future, albeit not necessarily a job that yields future economic returns. Others will not be able to engage in any regular job at all and will require intensive care for the rest of their lives. At this moment, the rate of employment for people with disabilities is only around 50 per cent (European Commission, 2010). This poses a serious problem to the central tenet of the social investment perspective, especially because its focus on social policy as a productive factor harnesses its view on citizenship in an economic fashion. The imperative is for employment to be maximised, and social policy ought to invest in people in order for them to realise their potential as (future) productive citizens. This offers little guidance, however, when it comes to realising the human potential of (future) citizens who may not be expected to be 'productive' in this sense, such as the mentally or physically impaired children introduced by Nussbaum. This does not only apply to disabled people, but also to the longer-term ill, the frail elderly, in short to anyone who is in dire need of care.

A broader but related issue is how unpaid care work is valued in the social investment state. Care is often provided in an informal way by (one of the) parents, and this is a fortiori true for the case of the disabled children. Research clearly shows, for instance, that having a disabled child negatively impacts on the propensity to work for one of the parents, in casu mothers (Ghysels and Van Vlasselaer, 2008). Moreover, people with disabilities have lower average levels of education (OECD, 2010), which means that the issue of unpaid care is more pressing in families with lower earning potentials and less labour market opportunities. Caregiving poses a particular problem for the idea of social inclusion through paid employment. What is the realistic and desirable obligation regarding paid 
work for parents who care for their disabled children? Should domestic care be rewarded in one way or the other? If so, in what cases? These are normative questions that directly impact on a central tenet of the social investment perspective.

What has the social investment literature to say on the issue of care? Virtually nothing. Neither the recent literature (for example, Morel et al., 2011; Bonoli and Natali, 2012) nor the canonical works (for example, Giddens, 1998; Esping-Andersen et al., 2002) explicitly mention, let alone discuss, how social policy should cope with people who need care and cannot be expected to contribute to the future sustainability of the welfare state on the one hand and people who do valuable and necessary but unpaid care work on the other. Giddens does acknowledge that the position of the frail elderly, 'who need continuous care' (1998: 125), raises difficult questions for social investment strategies, but does not make an attempt to solve the issue (see also Sevenhuijsen, 2000). Likewise, in Why We Need a New Welfare State the issue of informal caregiving for the frail elderly is only discussed in relation to redesigning pension systems (Esping-Andersen et al., 2002: 169). Certainly, this does not mean that the social investment perspective implies that people who need care do not deserve social protection, nor that social policy should remain absent when it comes to realising their human potential outside of the labour market. It does mean, however, that the issue of (giving or receiving) care is absent in the general framework of the social investment perspective. It is as though all productive citizens decide upon the balance between right and responsibilities in mutual agreement, only to realise afterwards that a whole group of people has been forgotten. As a consequence, the fate of those in need of care or giving care is treated as a mere afterthought from the social investment perspective. ${ }^{2}$ In such a context, care can easily be subsumed under the heading that it is every one's duty to engage in paid employment (Williams, 2012).

Indeed, employment reforms in European welfare states have been characterised by a strong emphasis on activation in order to increase labour market participation. Although here, too, countries differ in the details of employment policy reform, the social investment idea of social inclusion through employment has been generally pursued through two channels. On the one hand this has been done by extending the scope of activation policies to categories of people who were previously exempted from labour market participation, such as lone mothers and the disabled, and on the other hand by reinforcing work incentives and 'making work pay', by providing in-work benefits, subsidising low-productivity labour, but also by cutting back benefits, including disability and sickness benefits, and tightening eligibility requirements such as the compulsory acceptance of 'suitable jobs' (Eichhorst et al., 2008, Weishaupt, 2011; Clasen and Clegg, 2012). The Employment and Support Allowance in the UK is a clear example of an attempt to move people with disabilities into the workforce (Roets et al., 2012). Similar policies have been carried out in other countries (Annesley, 2007). In short, disability benefits are made less generous and eligibility is often tightened, while people with disabilities themselves are increasingly expected to engage in paid labour (OECD, 2010). But as we have seen above, people with severe mental or physical impairments cannot always be expected to be productive in this sense.

How do people with disabilities fare in a dual earner society where employment is imperative? While only 3 per cent of the population of active age declare themselves as being permanently disabled, they now represent 9 per cent of people at risk of poverty. Similarly, non-employed persons taking care of dependent persons, such as disabled children, face an above-average poverty risk, with a particularly high risk in the Southern 
European countries, but also in Belgium and Ireland (European Union, 2012). In sum, households with a person with a disability have a greater risk of social exclusion, and a work-first imperative without taking the issue of care into consideration might aggravate that risk for those who cannot be integrated into the labour market.

\section{The unbearable complexity of individual responsibility: the case of truancy}

In the social investment perspective, people are increasingly held responsible for their own welfare. As a consequence, governments deploy policy tools which are shaped by the very notion of responsibility: individuals are steered in the direction of 'appropriate behaviour' by means of carrots (for example, in-work benefits to 'make work pay') and sticks (for example, the curtailing of benefit entitlements to compel benefit claimants to take up work) (Gilbert and Van Voorhis, 2001). This has been extensively documented in the areas of labour market policy and social assistance in almost all European welfare states (supra), but conditional policies of this kind are increasingly deployed in other policy domains, such as education. Several examples of such policies, such as enabling the suspension or cancellation of income support payments or issuing administrative fines to parents whose child is not enrolled in school or is a persistent truant, are found in Belgium, The Netherlands, France and the United Kingdom, among others. Moreover, the CSB MIPI database $^{3}$ (Van Mechelen et al., 2011) shows that the conditionality of child benefits on school enrolment is today a common practice in several Central and Eastern European EU member states. There are numerous other examples of conditional and disciplinary policies ('behavioural management contracts'), such as jobseekers agreements, youth offender contracts, parenting contracts (Vincent-Jones, 2009). Proponents of the role of conditionality in benefit entitlement often argue that these improve outcomes for the targeted population. For instance, by requiring beneficiaries to send their children to school, conditionality is assumed to enhance human capital and further labour market outcomes (Bastagli, 2008).

In reality, however, the dividing line between effort, for which people are held responsible, and circumstances, for which they are not held responsible, is very thin. Drawing on the example of truancy policy in the Belgian region of Flanders, we will argue that in practice the notion of individual responsibility is not a good guidance for the constitution of fair social policy, let alone for the deployment of punitive measures, because of the unbearable complexity of the concept of responsibility (see Cantillon and Van Lancker, 2012, for a full elaboration of this argument). That is the second shortcoming of the social investment perspective: the deployment of disciplinary policies guided by the notion of individual responsibility, without being able to genuinely separate choice from circumstance, entails the danger of reinforcing existing inequalities.

Since the 1990s, Flemish educational policy has been strongly characterised by the ideal of equal opportunities. The government aspires for everyone to reap the fruits of high-quality education. To achieve this, free elementary and secondary education is provided, and families who cannot afford the additional costs of schooling (such as afterschool care, transportation and extracurricular activities) are entitled to a means-tested school allowance. The allowance is thus, by definition, targeted at financially vulnerable families. However, the provision of school allowances is not only an instrument of targeted solidarity, but also one of discipline. Parents of students who are either absent from school without authorisation for more than thirty half days in two consecutive years, or not 
officially registered for more than fifteen consecutive days, have to repay their allowance. Between its implementation in 2008 and 2010, 351 allowances were recovered (Cantillon and Van Lancker, 2012). If one fails to attend school, is it not simply a matter of fairness that one loses entitlement to a school allowance? This argument boils down to one of the central tenets of social investment: the association of merit with responsibility. Who is responsible for the socially aberrant behaviour, and to what extent?

To fully understand the significance of this issue, one has to go back to the beginning: the accident of being born into a disadvantaged or privileged family. Many of the inequalities, disadvantages and wrongdoings we observe in contemporary society find their origins in the lottery of birth. Obviously, no-one can be held responsible for being born. Furthermore, several crucial elements are more or less fixed at birth, not only genetic endowments, cognitive abilities and talents, but also parental educational attainment, socio-economic background of the family, the quality of the house in which one lives, the neighbourhood in which one grows up. More than a century of historical, sociological, economic and psychological research has made very clear how determining those contextual factors are in becoming an 'autonomous individual'. Children growing up in precarious neighbourhoods where social problems cumulate, which is incidentally a largely urban phenomenon, begin their adult lives with a disadvantage they are often not able to overcome.

Now let us turn to the profile of persistent truants in Flanders. Administrative data show that students of non-native descent, students with poorly educated parents and students from families entitled to a school allowance are overrepresented (Cantillon and Van Lancker, 2012). Moreover, the problems are relatively concentrated in urban areas. Obviously, it is not a coincidence that we recognise the same characteristics of vulnerability as outlined above in the profile of truants, and that families entitled to school allowances are overrepresented. The social gradient in truancy is not restricted to the Flemish case alone, but is universally found (see for instance Claes et al., 2009).

Given all this, to what extent is individual responsibility a useful concept to support disciplinary policy? In this case, the measure is aimed at parents in order to raise their awareness about the importance of education. The parents are thus held responsible for the behaviour of their children. Net of the de jure responsibility parents have for their children, we are here concerned with the de facto responsibility. Holding parents accountable for the absenteeism of their children does not take into account the unbearable complexity of the concept of responsibility: seldom clear-cut, almost always equivocal and ambiguous.

Consider the following examples. Can we hold the single mother responsible for the regular absenteeism of one of her children when she is time-constrained by combining paid employment with the care for all of her children and doing the household chores? Should we punish the migrant mother who is unable to untangle Flemish laws on compulsory schooling? And what about the short-term perspective of a sixteen-yearold preferring quick money in the informal circuit above the longer-term perspective of graduating, and who has never seen among her peers and kin that education effectively leads to a decent job? These examples illustrate how hard the task is to exactly demarcate responsibility. Do we blame the parent(s) or the child? Is it a matter of insufficient social protection for vulnerable households, which makes it a collective responsibility? And what about the responsibility of the school and the school system? Research shows that truancy occurs least in schools with a strong commitment to providing support for pupils, including a clear focus on their well-being (Claes et al., 2009). Conversely, truancy frequently occurs 
in schools where negative features (such as inadequate infrastructure, shortage of teachers and lack of funding) are cumulated. More generally, school systems reproduce existing socio-economic inequalities (Dronkers, 2010). Again we are confronted with the same dilemma: is it the collective or individual responsibility, or both?

Popular discourse would say that people are responsible for their own (mis)fortune when it is a consequence of their own actions or choice. Hence, if people 'choose' not to comply with the entitlement conditions (in this case coercing their children to attend school), they have no one but themselves to blame (for example, Goodin, 1988). Such a narrow view of responsibility however denies the context-specific nature of human agency and the unequal distribution of opportunities, which in itself shapes the range of choices open to people. In such a context, disciplinary policy measures conditional on responsible behaviour, the kind of behaviour that is determined by all sorts of complex interactions, are deemed to reinforce existing inequalities. Going back to our case of truancy, households entitled to school allowances are financially deprived by definition. Punishing these families by retracting these allowances (sometimes substantial amounts ranging from $€ 100$ to $€ 2,854$ for a secondary school student) may very well worsen their financially precarious situation.

Truancy is a complex phenomenon affected by a myriad of factors related to an unequal distribution of resources and opportunities. It is particularly a problem among vulnerable families with a precarious socio-economic profile whose children are generally enrolled in educational levels with less favourable labour market perspectives, the same families that are entitled to school allowances in the first place. The use of financial disincentives as a disciplinary measure, aimed at exactly those vulnerable families, will only add to their problems. The main point to take from this is that complex issues such as truancy cannot be reduced to a single cause, in this case 'flawed parents'. Such an approach only serves to scapegoat parents of truanting children whilst overlooking the real issue at stake: how to ensure an equal start for all children?

\section{The failure of human capital investment foretold: the case of childcare}

Ensuring an equal start for all children alike is indeed key to any successful investment strategy. Not only because the sustainability of the welfare state hinges on the number and productivity of future taxpayers, but also, and perhaps foremost, because inequalities in childhood pose a real threat to the accumulation of human capital and are a root cause of unequal opportunities in the labour market and later life (Vandenbroucke et al., 2011). Although human capital investment can be achieved amongst working age adults through life-long learning initiatives and promoting on-the-job training, at this point most European governments have focused on the expansion of early childhood education and care (ECEC, henceforth childcare) services (Van Lancker and Ghysels, 2013). The idea is that childcare services not only help to achieve social inclusion through the labour market, by allowing mothers of young children to engage in paid employment and balance their work and family duties, but also by furthering the human capital of children by means of a high-quality and stimulating environment (Shonkoff and Phillips, 2000; Heckman, 2006; Ruhm and Waldfogel, 2012). Both dimensions should be particularly beneficial for children from a disadvantaged background, ultimately breaking the intergenerational chain of poverty (Brooks-Gunn, 2003; Sylva et al., 2004). This so-called 'child-centred investment strategy' is heavily influenced by the assumption that public investments early 
on yield significant returns in later life in forgone benefits and reduced crime rates (EspingAndersen et al., 2002; Carneiro and Heckman, 2003). In short, qualitative childcare services should ensure a good start for all children alike.

The expectations regarding the benefits of early human capital investment policies for reducing poverty and inequality may, however, be too optimistic, because it can be expected that government investment in childcare services will first and foremost benefit higher income groups due to its underlying employment logic. In effect, given the persistent gendered division of household and care work, childcare acts as a precondition for maternal employment (in the absence of informal care alternatives) and it is quite obvious that demand will be higher among employed parents. Given the fact that, firstly, childcare supply is rationed in all European countries but the Scandinavian ones (Plantenga and Remery, 2009); and that, secondly, dual earnership is not equally dispersed among income strata, with higher educated women being more often employed and living in a dual earner household (Cantillon et al., 2001; Evertsson et al., 2009), childcare use will be biased against those with lower incomes. Consequently, government investment can be expected to flow first and foremost towards dual earner households, which have more financial resources at their disposal and thus more opportunities to ensure their children a better future (Ghysels and Van Lancker, 2011; Van Lancker and Ghysels, 2012).

Research shows that the disparity in average use of childcare services among young children (below the age of three) across European countries is enormous, ranging from more than 60 per cent in Denmark and Sweden to less than 5 per cent in the Czech Republic and the Slovak Republic (Ghysels and Van Lancker, 2011). This means that a significant share of young children do not benefit from childcare services at the moment. Moreover, among those children enrolled in childcare, children from high-income families are overrepresented. Children from low-income families use childcare to a much lesser extent than children from high-income families, and the same holds for children having a low-skilled mother vis-à-vis children having a higher skilled mother. And although Denmark and Sweden display the most equal distribution of childcare use of all European countries, there, too, the pattern is socially stratified (Van Lancker and Ghysels, 2013).

Hence the third shortcoming: when policy measures are grafted on an underlying logic of (previous) employment, then government investment benefits those already betteroff. The main beneficiaries of government investments in childcare are the children growing up in families with better future prospects. They are able to enhance their existing advantage through the benefits of childcare while children from low-income families face a 'double disadvantage' (UNICEF, 2008) - the reverse of what is aimed for. This phenomenon has been designated a 'Matthew effect', after the gospel of Matthew (for further reading see Rigney, 2010). Important to acknowledge here is that even in the two countries where childcare services are implemented in such a way that its use is most equally distributed across social groups, i.e. Denmark and to a lesser extent Sweden, not all families reap the fruit of qualitative childcare (Van Lancker and Ghysels, 2012). Even when carefully designed and optimally available, human capital investment through childcare will not be feasible for all children and families.

\section{Discussion: the future of social investment}

We have argued that the social investment perspective has some serious shortcomings, both inherently and in practice, when it comes to the social protection of vulnerable 
groups in society: disabled people and their caregivers, truants and children living in poor families. In order to be a fair and sustainable guiding principle for the future of social policy, these shortcomings have to be addressed. First, the balance between rights and responsibilities in the labour market should be redressed, taking the issue of care explicitly into account, which should lead to a strategy on how to ensure a decent living standard for caregivers as well as for people in need of care. Second, great circumspection is warranted in implementing policies that are built on a narrow notion of individual responsibility. They entail the danger of blaming the victim and reinforcing existing inequalities whilst overlooking the strong social gradient in many behavioural patterns. Third, the case of childcare shows that one should not be overly optimistic about the potential of human capital investment for combatting social inequalities, because of the presence of Matthew effects.

More generally, the three shortcomings we have identified in this article are all strongly related to the continuing relevance of social class in explaining and remedying social inequalities. Although some observers have made the point that modern societies have freed themselves from social class and traditional bonds and transformed into a place where everyone has the opportunity to be the master of their own fate, time and again research shows that peoples' welfare and opportunities are just as determined by their background and origin as they were half a century ago (Erikson and Goldthorpe, 1992). Social risks that are likely to induce poverty (for example, unemployment, illness and disability, early school dropout, low levels of education, divorce) are socially stratified across all welfare states, including the Scandinavian ones (Pintelon et al., 2013). This brings us back to the ambiguity of the social investment perspective with regard to the role of social protection identified in the introduction. We believe that our examples clearly demonstrate that a social investment perspective cannot and will not ensure social progress for all if it is not complemented by a firm commitment to traditional forms of social protection. Investment cannot be the only rationale for welfare state intervention; protecting people should remain equally high on the policy agenda.

\section{Notes}

1 This goes back to the ideas of Gunnar Myrdal in the 1930s, see Morel et al. (2011) for further reading.

2 We are inspired by Martha Nussbaum's reasoning in her discussion on the treatment of mental impairments in John Rawls' Theory of Justice: 'people with mental impairments are not among those for whom and in reciprocity with whom society's basic institutions are structured' (2006: 98).

3 The CSB MIPI (Minimum Income Protection Indicators) Database is a national expert sourced database containing data relating to social assistance and minimum wages as well as data on rules and legislations with regards to benefits and allowances for the EU25 countries. See http://www.centreforsocialpolicy.eu/ for more information and terms of use.

\section{References}

Annesley, C. (2007) 'Lisbon and social Europe: towards a European "adult worker model" welfare system', Journal of European Social Policy, 17, 3, 195-205.

Bastagli, F. (2008) 'Conditionality in public policy targeted to the poor: promoting resilience?', Social Policy and Society, 8, 1, 127-40. 
Bonoli, G. and Natali, D. (eds.) (2012) The Politics of the New Welfare State, Oxford: Oxford University Press.

Brooks-Gunn, J. (2003) 'Do you believe in magic?: what we can expect from early childhood intervention programs', Social Policy Report, 17, 1, 3-14.

Cantillon, B. (2011) 'The paradox of the social investment state: growth, employment and poverty in the Lisbon era', Journal of European Social Policy, 21, 5, 432-49.

Cantillon, B. (2013) 'Beyond social investment. Which concepts and values for social-policy making in Europe?', in B. Cantillon and F. Vandenbroucke (eds.), For Better For Worse, For Richer For Poorer: Labour Market Participation, Social Redistribution and Income Poverty in the EU, Oxford: Oxford University Press.

Cantillon, B., Ghysels, J., Mussche, N. and van Dam, R. (2001) 'Female employment differences, poverty and care provisions', European Societies, 3, 4, 447-69.

Cantillon, B. and Van Lancker, W. (2012) 'Solidarity and reciprocity in the social investment state: what can be learned from the case of Flemish school allowances and truancy?', Journal of Social Policy, $41,4,657-75$.

Cantillon, B. and Vandenbroucke, F. (eds.) (2013) For Better For Worse, For Richer For Poorer: Labour Market Participation, Social Redistribution and Income Poverty in the EU, Oxford: Oxford University Press.

Carneiro, P. and Heckman, J. (2003) 'Human capital policy', in J. J. Heckman, A. B. Krueger and B. M. Friedman (eds.), Inequality in America: What Role for Human Capital Policies?, Cambridge, MA: MIT Press.

Claes, E., Hooghe, M. and Reeskens, T. (2009) 'Truancy as a contextual and school-related problem: a comparative multilevel analysis of country and school characteristics on civic knowledge among 14 year olds', Educational Studies, 35, 2, 123-42.

Clasen, J. and Clegg, D. (2012) 'Adapting labour market policy to a transformed employment structure: the politics of "triple integration"', in G. Bonoli and D. Natali (eds.), The Politics of the New Welfare State, Oxford: Oxford University Press.

Daly, M. (2012) 'Paradigms in EU social policy: a critical account of Europe 2020', Transfer: European Review of Labour and Research, 18, 3, 273-84.

Dronkers, J. (2010) Quality and Inequality of Education, Dordrecht/London: Springer.

Eichhorst, W., Kaufmann, O. and Konle-Seidl, R. (2008) Bringing the Jobless into Work?: Experiences with Activation Schemes in Europe and the US, Berlin: Springer.

Erikson, R. and Goldthorpe, J. H. (1992) The Constant Flux: A Study of Class Mobility in Industrial Societies, Oxford: Clarendon Press.

Esping-Andersen, G., Gallie, D., Hemerijck, A. and Myles, J. (2002) Why We Need a New Welfare State, Oxford: Oxford University Press.

European Commission (2010) European Disability Strategy 2010-2020: A Renewed Commitment to a Barrier-Free Europe, COM(2010) 636 final, Brussels: European Commission.

European Union (2012) Employment and Social Developments in Europe 2011, Luxembourg: Publications Office of the European Union.

Evertsson, M., England, P., Mooi-Reci, I., Hermsen, J., De Bruijn, J. and Cotter, D. (2009) 'Is gender inequality greater at lower or higher educational levels? Common Patterns in the Netherlands, Sweden, and the United States', Social Politics, 16, 2, 210-41.

Giddens, A. (1998) The Third Way: The Renewal of Social Democracy, Cambridge: Polity Press.

Gilbert, N. and Van Voorhis, R. (2001) Activating the Unemployed: A Comparative Appraisal of WorkOriented Policies, New Jersey: Transaction Publishers.

Ghysels, J. and Van Lancker, W. (2011) 'The unequal benefits of activation: an analysis of the social distribution of family policy among families with young children', Journal of European Social Policy, 21, 5, 472-85.

Ghysels, J. and Van Vlasselaer, E. (2008) 'Child well-being in Flanders: a multidimensional account', Social Indicators Research, 89, 2, 283-304. 
Goodin, R. E. (1988) 'Social welfare as a collective responsibility', in D. Schmidts and R. E. Goodin (eds.), Social Welfare and Individual Responsibility, New York: Cambridge University Press.

Heckman, J. J. (2006) 'Skill formation and the economics of investing in disadvantaged children', Science, 312, 5782, 1900-02.

Hemerijck, A. (2012) 'Stress-testing the New Welfare State', in G. Bonoli and D. Natali (eds.), The Politics of the New Welfare State, Oxford: Oxford University Press.

Hemerijck, A. (2013) 'The reform capacities of European welfare states', in B. Cantillon and F. Vandenbroucke (eds.), For Better For Worse, For Richer For Poorer: Labour Market Participation, Social Redistribution and Income Poverty in the EU, Oxford: Oxford University Press.

Jenson, J. (2012) 'A new politics for the social investment perspective: objectives, instruments, and areas of intervention in welfare regimes', in G. Bonoli and D. Natali (eds.), The Politics of the New Welfare State, Oxford: Oxford University Press.

Jenson, J. and Saint-Martin, D. (2003) 'New routes to social cohesion? Citizenship and the social investment state', Canadian Journal of Sociology, 28, 1, 77-99.

Lister, R. (2003) 'Investing in the citizen-workers of the future: transformations in citizenship and the state under New Labour', Social Policy and Administration, 37, 5, 427-43.

Morel, N., Palier, B. and Palme, J. (eds.) (2011) Towards a Social Investment Welfare State? Ideas, Policies and Challenges, Bristol: The Polity Press.

Nussbaum, M. (2006) Frontiers of Justice: Disability, Nationality, Species Membership, Cambridge, MA: Harvard University Press.

OECD (2010) Sickness, Disability and Work: Breaking the Barriers. A Synthesis of Findings across OECD Countries, Paris: OECD.

Palier, B. (ed.) (2010) A Long Goodbye to Bismarck? The Politics of Welfare Reform in Continental Europe, Amsterdam: Amsterdam University Press.

Peña-Casas, R. (2012) 'Europe 2020 and the fight against poverty and social exclusion: fooled into marriage?', in D. Natali and B. Vanhercke (eds.), Social Developments in the European Union 2011, Brussels: ETUI.

Peng, I. (2011) 'Social investment policies in Canada, Australia, Japan, and South Korea', International Journal of Child Care and Education Policy, 5, 1, 41-53.

Pintelon, O., Cantillon, B., Van den Bosch, K. and Whelan, C. (2013) 'The social stratification of social risks: the relevance of class for social investment strategies', Journal of European Social Policy, 23, 1, 52-67.

Plantenga, J. and Remery, C. (2009) The Provision of Childcare Services: A Comparative Review of 30 European Countries, Luxembourg: Office for Official Publications of the European Communities.

Rigney, D. (2010) The Matthew Effect: How Advantage Begets Further Advantage, New York: Columbia University Press.

Roets, G., Roose, R., Claes, L., Vandekinderen, C., Van Hove, G. and Vanderplasschen, W. (2012) 'Reinventing the employable citizen: a perspective for social work', British Journal of Social Work, 42, 94-110.

Ruhm, C. and Waldfogel, J. (2012) 'Long-term effects of early childhood care and education', Nordic Economic Policy Review: Economics of Education, 1/2012, Copenhagen: Nordic Council of Ministers.

Sevenhuijsen, S. (2000) 'Caring in the third way: the relation between obligation, responsibility and care in Third Way discourse', Critical Social Policy, 20, 1, 5-37.

Shonkoff, J. P. and Phillips, D. A. (2000) From Neurons to Neighbourhoods: The Science of Early Childhood Development, Washington, DC: National Academy Press.

Sylva, K., Melhuish, E., Sammons, P. and Siraj-Blatchford, I. (2004) The Effective Provision of Pre-School Education (EPPE) Project: Final Report, A Longitudinal Study Funded by the DfES 1997-2004, London: Institute of Education.

Taylor-Gooby, P. (2008) 'The new welfare state settlement in Europe', European Societies, 10, 1, 3-24.

Taylor-Gooby, P. (2011) 'Opportunity and solidarity', Journal of Social Policy, 40, 3, 453-70. 
UNICEF (2008) The Child Care Transition, Innocenti Report Card 8, Florence: UNICEF Innocenti Research Centre.

Vandenbroucke, F. and Vleminckx, K. (2011) 'Disappointing poverty trends: is the social investment state to blame? An exercise in soul-searching for policymakers', Journal of European Social Policy, 21, 5, 450-71.

Vandenbroucke, F., Hemerijck, A. and Palier, B. (2011) The EU Needs a Social Investment Pact, OSE Paper Series, Opinion paper No. 5, Brussels: Observatoire social européen.

Van Lancker, W. and Ghysels, J. (2012) 'Who benefits? The social distribution of subsidized childcare in Sweden and Flanders, Acta Sociologica, 55, 2, 125-42.

Van Lancker, W. and Ghysels, J. (2013) 'Who benefits from investment policies? The case of family activation in European countries', in B. Cantillon and F. Vandenbroucke (eds.), For Better For Worse, For Richer For Poorer: Labour Market Participation, Social Redistribution and Income Poverty in the EU, Oxford: Oxford University Press.

Van Mechelen, N., Marchal, S., Goedemé, T. and Cantillon, B. (2011) The CSB-Minimum Income Protection Indicators Dataset (CSB-MIPI), Antwerp: Herman Deleeck Centre for Social Policy, University of Antwerp.

Vincent-Jones, P. (2009) 'Individual responsibility and welfare contractualism: a relational evaluation', The Social Contract Revisited, Oxford: The Foundation for Law, Justice and Society.

Weishaupt, J. T. (2011) From the Manpower Revolution to the Activation Paradigm Explaining Institutional Continuity and Change in an Integrating Europe, Amsterdam: Amsterdam University Press.

Williams, F. (2012), 'Care relations and public policy: social justice claims and social investment frames', Families, Relationships and Societies, 1, 1, 103-19. 